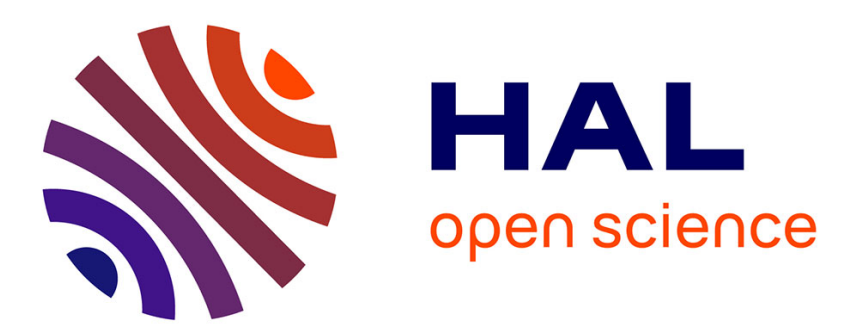

\title{
Title: UV_Visible and Fluorescence Green Waste Composts Monitoring: Material Dependency
}

\author{
M. G Abaker, M. Domeizel, O. R Mouloubou, N. Rapetti, Stéphane Mounier
}

\section{To cite this version:}

M. G Abaker, M. Domeizel, O. R Mouloubou, N. Rapetti, Stéphane Mounier. Title: UV_Visible and Fluorescence Green Waste Composts Monitoring: Material Dependency. Compost Science \& Utilization, 2018, pp.1 - 12. 10.1080/1065657X.2018.1434023 . hal-01879414

\section{HAL Id: hal-01879414 https://hal.science/hal-01879414}

Submitted on 23 Sep 2018

HAL is a multi-disciplinary open access archive for the deposit and dissemination of scientific research documents, whether they are published or not. The documents may come from teaching and research institutions in France or abroad, or from public or private research centers.
L'archive ouverte pluridisciplinaire HAL, est destinée au dépôt et à la diffusion de documents scientifiques de niveau recherche, publiés ou non, émanant des établissements d'enseignement et de recherche français ou étrangers, des laboratoires publics ou privés. 
Title :

\section{UV-Visible and Fluorescence Green Waste Composts Monitoring: Material}

\section{Dependency}

M. G. Abaker ${ }^{(\mathrm{a}, \mathrm{b}, \mathrm{c})^{*}}$, M. Domeizel ${ }^{(\mathrm{b})}$, O. R. Mouloubou ${ }^{(\mathrm{b})}$, N. Rapetti ${ }^{(\mathrm{c})}$, S. Mounier $^{(\mathrm{a})}$

(a) Université de Toulon - CS 60584, Laboratoire PROTEE, 83041 TOULON CEDEX 9, France

(b) University Aix-Marseille, LCE Laboratory, place Victor Hugo, 13331 Marseille Cedex 3, France

(c) Micro-Terra, ZA Espace Lunel Littoral, 177 B, Avenue Louis Lumière, 34400 Lune, France

* Corresponding author e-mail: mounier@univ-tln.fr

\section{Abstract :}

The most frequent way to survey green waste composts is to monitor the temperature during the composting process. However, if the temperature is a good index for global biological processes, it is not for the chemical stability. In order to identify a reliable index, this work investigates water extraction coupled to spectroscopic indexes such as $\mathrm{E}_{2} / \mathrm{E}_{3}, \mathrm{E}_{4} / \mathrm{E}_{6}$ and $\mathrm{SUVA}_{254}$ ratios, and fluorescence indexes such as Kalbitz, Milori, CP/PARAFAC and Fluorescence Region Integration. The measurements of these indexes are carried out with six samples from different sites with different green waste material composition. The results show that most indexes depend on the green waste origin more than the composting time; some depend mostly on the material origin while others on compost age. A comparison of these results indicates that the biochemical 
process occurs more rapidly than expected by the compost producers. The combination of these indicators gives useful information on the processes that take place during composting.

\section{Introduction}

The composting process is based on two phenomena; firstly on bio-oxidation reactions in the aerobic environment and secondly on molecular reorganization leading to a partial humification of the organic matter. After an optimum rest time, the result is humified compost. Composting is also defined as a controlled process of degradation of organic constituents of plant and animal origin, by a succession of microbial communities evolving under aerobic conditions, resulting in a rise in temperature, and development of stabilised humified organic matter. The resulting product is called compost (de Bertoldi et al., 1983). Degradation of organic matter through composting is needed to improve the biological, chemical and physical properties of soil. These composts can be used to 1) improve soil structure, 2) increase organic matter in soil, and 3) provide nutrients to plants for accelerating their growth (Bernal et al., 1998). Furthermore, composts can be used for remediation of soils contaminated with toxic organic compounds (Amine-Khodja et al., 2006). Composts can be made from different sources of waste such as animal manures, water treatment plant mud, alimentary waste and vegetation waste. Grass clippings, dead leaves and pruning branches are distinguished from the others as green wastes. Only mature compost is of interest for agriculture since unstable or immature compost is prone to problems such as deprivation of nitrogen for plants along with phytotoxicity by competition of oxygen (Bernal et al., 1998; Gómez-Brandón et al., 2008). In order to evaluate the maturity and chemical 
stability of compost, time consuming measurements have to be performed. These include processes such as respirometry, carbon and nitrogen content determination and germination tests. As a result, they are difficult to apply to real time surveys or large sets of data (Bernal et al., 1998). To overcome this, the optical properties of the extracted organic matter have been investigated to find a proxy for the evaluation of chemical stability. Indeed, compost management is often done only after temperature stabilisation, or after an empirical time defined by the compost producers. Several studies were done based on various types of input (cattle manure, green waste and winery waste), and these are often used as co-compost with green wastes (Wei et al., 2014). Only a few studies have investigated the best way to monitor compost evolution. One example that stands out is the usage of fluorescence spectroscopy to define a multivariate optical formula to assess the maturity of various animal manure or industrial organic final products (Yu et al., 2010). Fluorescence and UV-Visible spectroscopy have also been used to monitor the process of composting, generally for a duration of three or four months, until the temperature of the compost has decreased and stabilised (Li et al., 2014; Marhuenda-Egea et al., 2007; Sellami et al., 2008; Tang et al., 2011). For winery waste and animal manure it is generally observed that the carbon to nitrogen ratio $(\mathrm{C} / \mathrm{N}$ ratio), percentage of carbon $(\% \mathrm{C})$ and protein fluorescence decreases while the humic acid (HA) over fulvic acid (FA) ratio increases at the same time at their fluorescence signal (Domeizel et al., 2004; Marhuenda-Egea et al., 2007; Tang et al., 2011). The same results were observed on vermicompost by fluorescence spectroscopy using fluorescence regional integration (FRI) and the $\mathrm{E}_{4} / \mathrm{E}_{6}$ index (Zhang et al., 2015) and on cattle manure (He et al., 2013). Until now, only a few studies have been done solely on green waste composts (Domeizel et al., 2004; Khalil et al., 2008), 
as these types of waste are often used as co-composting material (Jouraiphy et al., 2005). However, it is important to study the maturation of this type of compost to help compost producers in compost permutation and turnover during production because green waste inputs are highly heterogeneous and season-dependent. The present work uses the optical properties of water extractable organic matter (WEOM, Said-Pullicino et al., 2007a; Shao et al., 2009) and extractable organic matter (EOM, Fuentes et al., 2006) to determine rapid and reliable indexes of process ending. Experiments were done on seven exclusive green waste composts (GW) located on six producer sites that were sampled monthly over a period of six months. The organic matter of the composts was extracted with a water (1 h, WEOM) and sodium hydroxide $(\mathrm{NaOH})$ solution $(24 \mathrm{~h}$, EOM) and extracts were analysed using the UV-Visible technique (Guo et al., 2012), 3D fluorescence spectroscopy (Tian et al., 2012), pH and dissolved organic carbon. Various parameters such as ultraviolet-visible (UV-vis) spectra, the $E_{2} / E_{3}, E_{4} / E_{6}$ ratios and SUVA $_{254}$ were measured. The $E_{2} / E_{3}$ ratio is used as an indicator of humification and of the molecular weight of humic substances (Peuravuori and Pihlaja, 1997; Duarte et al., 2003; Li et al., 2009). The $\mathrm{E}_{4} / \mathrm{E}_{6}$ ratio is widely used for the characterisation of humic substances (Chen et al., 1977; Senesi et al., 1991). SUVA 254 is widely used as an index for aromatic structures within dissolved organic matter (DOM) (Weishaar et al., 2003; Shao et al., 2009; Pifer and Fairey, 2012; Zhang et al., 2016). The Canonical Polyadic/PARAFAC (CP/PARAFAC) decomposition and FRI of excitation-emission matrix spectra is widely used-(Chen et al., 2003; Marhuenda-Egea et al., 2007; Yu et al., 2011; Zhou et al., 2012; Pype et al., 2013) to assess the compost maturity. The Milori index (Milori et al., 2002), the Kalbitz index (Kalbitz et al., 1999), the Hx index (Zsolnay et al., 1999) and the $\mathrm{R}_{\mathrm{a}, \mathrm{c}}$ (Mounier et al., 1999) were also investigated. 


\section{Materials and methods}

\subsection{Sampling and pre-treatment}

The GW used in this study were collected on various organic waste composting sites in an aerobic environment, located in the south of France. They were from the cities of Agde (43.288551, 3.514246), Marsillargues (43.661910, 4.178902), Signes (43.288648, 5.852698) and Fréjus (43.440724, 6.707701). Each composting site was fuelled by different types of green waste, mainly consisting of dead leaves, pieces of wood, tree and herb prunings from individuals and municipal cleaning. All these vegetable wastes were produced and deposited on a soil to form a 50 to $5 \times 2 \times 2$ m windrow, depending on the site. In order to maintain the aerobic conditions during the composting process, the swath was returned using a windrower. The temperature was measured every month at a depth of $80 \mathrm{~cm}$ at different locations of the swath. Samples were taken monthly. Each sample was divided into four parts. Two quarters were merged and distributed again to obtain four new sub-samples. From one of the last sub-samples, ten grams (10

g) were sampled to measure moisture by weight loss at $100{ }^{\circ} \mathrm{C}$, and the remainder was frozen for storage. The dried sample was used to measure the total organic carbon (TOC) of the solid sample in triplicate. The three remaining sub-samples were sampled and used for individual spectroscopic measurement. The obtained vlaues were averaged to obtain the field experimental variability.

\subsection{Extractions}


All the extractions were done at maximum 2 hours after sampling. The fresh samples were placed in a $50 \mathrm{~mL}$ plastic corning. WEOM was obtained by extracting samples with Milli-Q water (solid to water ratio of 1:10) and EOM was obtained by extracting with a 0.1 mol. $\mathrm{L}^{-1}$ solution of $\mathrm{NaOH}(\mathrm{pH}=12)$ with the same w/v ratio. The cornings were gently shacken for 1 hour (WEOM) and 24 hours (EOM) at 7 rpm using a rotary shaker HeildophReax at room temperature. The suspensions were then centrifuged at $2.012 \mathrm{~m} . \mathrm{s}^{-2}$ for $30 \mathrm{~min}$. A pH measurement was carried out at the end of the centrifugation ( $\mathrm{pH}_{\mathrm{wEOM}}$ of $\mathrm{pH}_{\mathrm{EOM}}$ ), and before filtration, with a HannaLab $\mathrm{pHmeter}$ after electrode calibration.

Then, extracts were filtered on cellulose nitrate filters $(0.22 \mu \mathrm{m})$ by means of an online filtration system (Sartorius stedim ${ }^{\circledR}$ ). Filtrates $(5 \mathrm{~mL}$ ) were collected in two glass tubes previously burned at $450{ }^{\circ} \mathrm{C}$ during 12 hours. The samples were then divided into two groups.

For the first group, the WEOM and EOM were preserved with $100 \mu \mathrm{L}$ of 1 mol.L ${ }^{-1}$ sodium azide ( $\mathrm{NaN}_{3}>99 \%$, Aldrich) and stored at $4{ }^{\circ} \mathrm{C}$ in the dark in order to measure the non-purgeable organic carbon (NPOC) and take spectroscopic measurements. The second group was frozen at $-20{ }^{\circ} \mathrm{C}$ in order to measure the total dissolved nitrogen (TDN).

\subsection{Spectroscopic measurements}


UV-Visible spectra were recorded from 200 to $800 \mathrm{~nm}$ at medium speed on a double beam UV-1800 (Shimadzu). Milli-Q water (C.E: $18 \mathrm{M} \Omega . c m$ at $\left.25{ }^{\circ} \mathrm{C}\right)$ or $\mathrm{NaOH}(0.1$ mol. $L^{-1}$ ) solutions were used as references for WEOM and EOM respectively. The $E_{2} / E_{3}$ ratio was calculated from the quotient between absorbance at 250 and $365 \mathrm{~nm}$, The $\mathrm{E}_{4} / \mathrm{E}_{6}$ ratio was calculated by dividing respectively absorbance at 465 and $665 \mathrm{~nm}$, and $\mathrm{SUVA}_{254}$ was the ratio of the absorbance at $254 \mathrm{~nm}$ (Abs 254) by UV cell path length (l) measured in (m), and the concentration of dissolved organic carbon (DOC) measured in milligrams per litre (mg.L) was calculated from these spectra as proxy of spectral slope and molecular size (Stevenson, 1982; Summers et al., 1987), humification and degradation (De Haan, 1983) and aromaticity respectively (Weishaar et al., 2003).

The same quartz SUPRASIL ${ }^{\circledR}$ cells were used for absorbance and fluorescence measurements. Excitation-emission matrix fluorescence (EEM) measurements were made with a HITACHI ${ }^{\circledR}$ F4500 spectrofluorimeter. Samples were diluted with a sodium bicarbonate $\mathrm{NaHCO}_{3}$ solution to obtain the same pH conditions until absorbance at 254 $\mathrm{nm}<0.1$ to avoid an inner effect (Luciani et al., 2009). Raman spectra (Ex/Em = 350/395 $\mathrm{nm}$ ) were recorded daily in order to verify excitation lamp calibration. The Raman fluorescence intensity variability was less than 5\% during all the measurements. 2D fluorescence wavelengths were used to follow several parameters: speed-scan of 240 nm. $\mathrm{min}^{-1}$, response mode auto, PMT $700 \mathrm{~V}$, excitation and emission slit at $5 \mathrm{~nm}$ and 10 $\mathrm{nm}$ respectively and wavelength range to measure $\mathrm{R}_{\mathrm{a}, \mathrm{c}}\left(\lambda_{\mathrm{ex}}=200-400 \mathrm{~nm}, \lambda_{\mathrm{em}}=420 \mathrm{~nm}\right)$ (Mounier et al., 1999), Kalbitz $\left(\lambda_{\mathrm{ex}}=300-520 \mathrm{~nm}, \lambda_{\mathrm{em}}=\lambda_{\mathrm{ex}}+55 \mathrm{~nm}\right)$ (Kalbitz et al., 1999) and Milori ( $\lambda_{\mathrm{ex}}=440 \mathrm{~nm}, \lambda_{\mathrm{em}}=350-650 \mathrm{~nm}$ ) (Milori et al., 2002). The 3D parameters of the spectrofluorimeter were set at $\left(\lambda_{\mathrm{ex}}=200-550 \mathrm{~nm}, \lambda_{\mathrm{em}}=200-600 \mathrm{~nm}\right.$, excitation and emission slit at $5 \mathrm{~nm}$, scan-speed at 2,400 nm.min ${ }^{-1}$, and response mode 
at $0.1 \mathrm{~s}$, PMT $700 \mathrm{~V})$. Excitation-emission matrices were extracted from the 3D spectra every $5 \mathrm{~nm}$ for excitation and emission by the FLSolution HITACHI software. Rayleigh and Raman diffusion were suppressed by the direct cut and numerical method before decomposition (Zepp et al., 2004). Fluorescence regional integration (FRI) was done directly on EEM (Chen et al., 2003) and has been used successfully in previous work (Chen et al., 2003; Wang et al., 2009) to characterise different organic matters and even to define compost maturation indexes (Tang et al., 2011; Yu et al., 2010). The best model of CP/PARAFAC decomposition was the one giving the higher number of component and CONCORDIA over 60\%, was chosen. In order to define green waste indexes, all the results were obtained by averaging the triplicate values, meaning that for each time and site, the index value was calculated as the average of the field sample triplicate.

\subsection{Chemical analysis}

The NPOC, after acidification ( $\mathrm{HCl}$, reagent grade), and TDN were measured using a Shimadzu TOC-V from the samples with and without $\mathrm{NaN}_{3}$ poisoning respectively. Calibration was done each day with a phthalic acid solution. When necessary, the sample was diluted to bring it into the calibration range. Total solid carbon- (TC) and total solid nitrogen (TN), were measured with a Shimadzu-CN instrument by introducing a small amount (mg) of sample in a $950{ }^{\circ} \mathrm{C}$ furnace. Calibration was done daily using L-Aspartic chemical and solid reference material of known $\mathrm{C}$ and $\mathrm{N}$ content.

\section{3- Results and discussion}


To determine what indicators statistically vary with time or with origin of the green waste matter (site), an analyse of variance (ANOVA) study was done for sites and time for all the measured indexes. The results are reported in Table 1.

\section{Table 1}

The time and site (TS) group showed significant differences during maturation time and sites, meaning that they had potential to be good indexes for monitoring both compost maturation and raw material origin. The fourth index from FRI calculation (QIV) is the unique in the time dependent group $(\mathrm{T})$ because it is more sensitive to the maturation time than to the sites. This is potentially a good indicator for maturation or stabilisation monitoring. In the site dependent group (S), the indexes show variations depending on green waste origin. Most of the indexes are located in the $\mathrm{N}$ group, meaning that they present a too high variability to identify any significant trend during compost maturation or to define the composition of the compost. It is important to keep in mind that the ANOVA is not a correlation test, but it gives useful information to choose indexes that could be good candidates for monitoring purposes as it reveals differences between times and sites. Whatever their group membership, the indexes are described later in this work as chemical stability compost indicators. Based on the ANOVA description, the boxcar plot was chosen to represent time variation in the different indexes.

\subsection{The composting process}

The variations in temperature recorded during the composting process (Fig. 1) followed an almost similar pattern to many composting platforms for organic waste (Mustin, 
1987, Tomati et al., 1995). Two phases were represented in this process. An initial phase was characterised by an increasing average temperature up to $50-70{ }^{\circ} \mathrm{C}$ (Agde $\left(68{ }^{\circ} \mathrm{C}\right.$ ), Fréjus $\left(57^{\circ} \mathrm{C}\right)$, Marsillargues $\left(59^{\circ} \mathrm{C}\right)$ and Signes $\left(70^{\circ} \mathrm{C}\right)$ ) in the first four months. This increase was mainly due to the different microbial populations that degraded green waste organic matter (Zhao et al., 2013). The increase in temperature made it possible to clean up the compost by killing most pathogens (Khalil et al., 2011; Nafez et al., 2015) and a large proportion of the weed seeds (Larney and Blackshaw, 2003). Then, during the maturation phase, the average temperature decreased (Agde $\left(50^{\circ} \mathrm{C}\right)$, Fréjus $\left(46^{\circ} \mathrm{C}\right)$, Marsillargues $\left(44^{\circ} \mathrm{C}\right)$ and Signes $\left(58^{\circ} \mathrm{C}\right)$, during the sixth month) over time. This reduction can be considered as stabilisation of the active humification of the organic matter with molecular recombinations allowing the humic compounds to appear.

Fig. 1- Temperature variations

For both extraction protocols, the $\mathrm{pH}_{\text {WEOM }}$ and $\mathrm{pH}_{\mathrm{EOM}}$ increased from the start to the end of maturation time and reached an average stabe maximum of nine before decreasing on the last month (Fig. 2). One can notice that for EOM, even though the $\mathrm{pH}$ of the extracting solution was at $12\left(0.1\right.$ mol. $\mathrm{L}^{-1}$ of $\left.\mathrm{NaOH}\right)$, the measured $\mathrm{pH}_{\mathrm{EOM}}$ values reached systematically lower values of around $\mathrm{pH}=9$. The $\mathrm{pH}_{\text {WEOM }}$ or $\mathrm{pH}_{\text {EOM }}$ increase might be due to the degradation of fatty acids or the release of ammonia during the alkalinisation phase during the composting process. Thus a plateau was reached after month 4 for the green waste composts. An explanation for the reduction of the $\mathrm{pH}$ in month 6 was that even if process details were given by the producers, at the end of the commercial process, it happened that some mixing occurred with different fresher 
composts, to reach an normed value allowing commercialisation. This $\mathrm{pH}$ behaviour was different from the co-composting or manure compost: in the case of green wastes, it seemed that the $\mathrm{pH}$ reached a higher value (around 8.5) instead of 6-7.5 for other type of inputs (Marhuenda-Egea et al., 2007; Tang et al., 2011; Zhang et al., 2015). The global increase was continuous, without an intermediate decrease as already observed (Tang et al., 2011). However, a higher $\mathrm{pH}$ could be observed in mature green waste compost (Wei et al., 2014).

Fig. $2-\mathrm{pH}$ variation

The average TC variation is given in Fig. 3. The $\mathrm{C}$ content was relatively constant ( $35 \mathrm{~g}$ of C. $\mathrm{kg}^{-1}$ ) during the first three months and then suddenly decreased to $30 \mathrm{~g}$ of C. $\mathrm{kg}^{-1}$. $\mathrm{TDN}_{\text {EOM }}$ and $\mathrm{TDN}_{\text {WEOM }}$ seemed to be constant, oscillating between $25 \mu \mathrm{mol.} \mathrm{L}^{-1}$ to 10

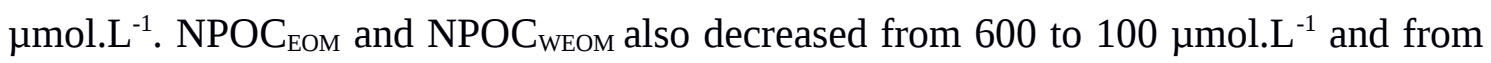
650 to $200 \mu \mathrm{mol} . \mathrm{L}^{-1}$ respectively. This trend was permanently observed for all compost types, due to mineralisation of the biomaterial (Said-Pullicino et al., 2007b). The C/N ratio of the extracted EOM and WEOM decreased as previously observed in manure and sludge co-composting. The reached values were consistent with those found for other types of compost (Wei et al., 2014; Zhang et al., 2015). However, the values were much higher than those found for WEOM of grape pomace compost (near 0.32) at the final stage (Bernal et al., 1998). It is obvious that for the present set of green waste composts, the variability of the value drastically decreased with time, meaning that whatever the input, the same final value was reached. 
Fig. 3 - TC and TN variations

UV-Visible indexes $E_{4} / E_{6}$ and $E_{2} / E_{3}$ ratio are presented in Fig. 4. A trend towards an increase in the $E_{4} / E_{6}$ ratio for WEOM could be described, from 4 to 6 , but for EOM there was high heterogeneity and no particular trend. These values had a similar trend to those observed for sludge co-composting, but with a decrease from 7.6 to 4.5 during the maturation time (Zhang et al., 2015). The same trend was observed for the $E_{2} / E_{3}$ index. These UV-Visible indexes were not enough dependent on both site, i.e. green waste origin and maturation time to be proxies of compost stabilisation.

Fig. 4 - UV-Visible variation

The average $\mathrm{SUVA}_{254}$ (Fig. 5) showed an increase for WEOM and EOM until the third month, and stayed at around a value of 0.03 for WEOM and 0.04 for EOM. However, once again the variability was high and showed a high dependency on the input matter. This trend was also observed for cattle manure for the first 40 days (He et al., 2013) and waste city co-composting (Said-Pullicino et al., 2007b). This behaviour was attributed to an increase of the phenolic moieties due to higher biodegradability of the hydrophilic compounds.

Fig. 5 - $\mathrm{SUVA}_{254}$ Variation

The average $\mathrm{R}_{\mathrm{a}, \mathrm{c}}$ index of WEOM and EOM increased but with high heterogeneity for the latter (Fig. 5). This index variation was opposite to those observed for cattle manure 
(He et al., 2013). In this work, the $\mathrm{R}_{\mathrm{a}, \mathrm{c}}$ increased from 0.8 to 1.4 , while it decreased from 1.66 to 1.55 in the case of cattle manure (He et al., 2013). In both cases, the 1.4 value seemed to be a common limit. For a green mature compost a value of 0.91 was observed in a 24-hour water extracted sample (Wei et al., 2014). During composting the quantity of FA should decrease while the quantity of HA increases. This was determined comparing initial and final composting processes. In this study, sampling was made during the maturation time and on different green wastes. The $\mathrm{R}_{\mathrm{a}, \mathrm{c}}$ increased probably due to a more rapid production of fulvic acid-like compounds than humic ones, revealing differences in kinetic production process. When the equilibrium process is reached the $R_{a, c}$ index remains constant. Thus, $R_{a, c}$ of WEOM was potentially a good index for biochemical stabilisation and maturation monitoring.

The Milori index (Fig. 6), $\mathrm{H}_{\mathrm{FIL}, \mathrm{WEOM}}$, decreased a little from the first month to the third, and increased until the sixth month. $\mathrm{H}_{\mathrm{FIL}, \mathrm{EOM}}$ showed a high variation compared to $\mathrm{H}_{\text {FIL,weom. }}$ The Milori index was not a good candidate for the green compost stabilisation, $\mathrm{H}_{\mathrm{FIL} \text {,EOM }}$ was more dependent on inputs than $\mathrm{H}_{\mathrm{FIL}, \mathrm{WEOM}}$ because its variability was much higher.

Fig. 6 - Milori index variation

The average Kalbitz indexes (Fig. 6) of WEOM and EOM clearly decreased during time composting from 10 to 4 . Surprisingly, the more sensitive Kalbitz index to input quality was the EOM one. Stabilisation of the Kalbitz signal was reached at the fourth month. 
PARAFAC components and their variations with composting time are presented in Fig. 7. Decomposition was done on the 6 months $\times 6$ sites $\times 3$ triplicates $\times 2$ extractions protocol $=236$ EEMs and a three-component model was selected with a 94\% CONCORDIA, and no outliers were observed. Component 1 (C1), component 2 (C2) and component 3 (C3) were respectively represented on lines A, B and C in Fig. 7. C1 presented a maximum peak at the Ex/Em wavelength of 325/415 nm and it could be related to the humic-like compounds in the region of the peak C (Coble, 1996; Parlanti et al., 2000). The C2 presented a double peak emission at $475 \mathrm{~nm}$ for 275 and $375 \mathrm{~nm}$ of excitation and could be related to more humificated or ligneous compounds. Finally, the C3 component peak was located at an Ex/Em wavelength of 275/350 nm which was the protein-like-compound position corresponding to biological activity. The stability of the $\mathrm{C} 1$ contribution of EOM and WEOM, and the increase of average $\mathrm{C} 2_{\text {WEOM }}$ and $\mathrm{C} 2_{\mathrm{EOM}}$ were consistent with the degradation of simple and biolabile molecules into humic-like compounds. However, humic acids with high molecular weight were produced and conserved preferentially to fulvic acids. This AH/AF ratio evolution was opposite to the $\mathrm{R}_{\mathrm{a}, \mathrm{c}}$ one which increased with time, but could be explained by the redshift of the $\mathrm{C} 2$ position while the $R_{a, c}$ index was calculated with the same emission wavelength, 420 $\mathrm{nm}$. Hence, during composting the fluorescence intensity at an Ex/Em wavelength of 250/415 nm decreased less rapidly than the C1 maximum. $\mathrm{R}_{\mathrm{a}, \mathrm{c}}$ and CP/PARAFAC gave complementary information on the extracted organic matter process: high molecular humic acid-like compounds were degraded or transformed preferentially, and it was the ligneous compounds that remained preferentially. Thus CP/PARAFAC in combination with other indexes was useful for monitoring molecular changes of compost. 
The decrease of the C3 (Fig. 7, line C) was important for one month and after, it slowed down at a consistent rate. The proteins' fluorescent response was more important in the first month due to bacterial activity. Thus, high microbial activity during the first month was confirmed in concordance with other works using 3D fluorescence (Coble, 1996; Parlanti et al., 2000; Baker, 2001; Baker, 2002; Stedmon et al., 2003). The dependency on the input material was higher for the $\mathrm{C} 1$ and $\mathrm{C} 2$ components than for $\mathrm{C} 3$. As for the $\mathrm{C} / \mathrm{N}$ ratio, it seemed that dependency was important at the beginning, in the first month, and reached exponentially an asymptotic response .

\section{Fig. 7 -PARAFAC component variations}

Based on the 3D fluorescence response, FRI was calculated for all the samples. The QI and QII fractions were related to simple aromatic proteins, such as tyrosine and tryptophan, while QIII was related to recently degraded organic matter. QIV was related to fulvic acid presence and QV to humic acid. To compare the variation of the QI, QII, QIII, QIV and QV values in this work, the time set values were normalized to the value of the first sample (T1) for WEOM and EOM, corresponding to the raw material, and the mean of each normalized FRI region was calculated with corresponding standard deviation, using WEOM and EOM together as they were highly correlated $\left(\mathrm{R}^{2}=0.89\right)$. The obtained results are presented in Fig. 8. The QI and QII fractions showed a slight increase for two months (T1 to T3) and had stabilised by the end of the experiment. The increase of QI and QII during this period was not in agreement with the variation observed by Tang et al. (2011) for swine manure, rice husk and straw, or that observed by Tian-et al. (2012) from dairy manure and rice chaff, or by Marhuenda-Egea et al. 
(2007) for winery and distillery residues. Concerning the QIII fraction, once again the behaviour was contrary to those found for swine manure, rice husk and straw (Tang et al., 2011), but in accordance with dairy manure, where it stayed constant, or with winery and distillery residues where it increased. The QIV and QV fractions stayed constant in this work. In other work, for swine manure, QIV and QV increased during the first month (Tang et al., 2011), while for dairy manure and winery and distillery residue, QIV decreased while QV increased (Marhuenda-Egea et al., 2007). QIV and QV were related to humic and fulvic acid but in our case, the contribution to fluorescence of extractable OM did not vary. On another way, the QI, QII and QIII increased until the second month and stayed stable.

Fig. 8 - FRI variations.

\section{Conclusions}

The critical information during compost production is to know when the compost reaches stability or maturity. The fast and common is the inside pile temperature which should be related to microbial activity but is not necessarily good parameter. This work on green waste composts showed that the $\mathrm{pH}$ and the $\mathrm{R}_{\mathrm{a}, \mathrm{c}}$ fluorescent indexes were potentially good indexes to determine the compost biochemical stabilisation by their behaviours during maturation time and related to WEOM. Both the $\mathrm{pH}$ and $\mathrm{R}_{\mathrm{a}, \mathrm{c}}$ of WEOM were fast measurements that could be done on site. Measurement on waterextracted organic matter was efficient, and showed a stabilisation after three months of composting. 
This work also demonstrated that most of the indexes developed in the past and in this work were highly dependent on the input material. This indicated that it would be difficult to define the maturity, stabilisation or age of a compost by measuring only one value or a universal parameter. Results showed that the non-dependent parameters on green compost inputs were the $\mathrm{C} / \mathrm{N}$ ratio, Kalbitz and the CP/PARAFAC C3 component, at the end of the time process. Finally, the $\mathrm{R}_{\mathrm{a}, \mathrm{c}}$ and $\mathrm{pH}$ measurements were highly negatively correlated to the $\mathrm{C} / \mathrm{N}$ ratio, which was a time-consuming chemical parameter. To monitor the compost chemical stabilisation with an on-site rapid, low cost and timesaving method, the best way is to combine the inside pile temperature, $\mathrm{pH}$ and $\mathrm{R}_{\mathrm{a}, \mathrm{c}}$ index of the WEOM.

\section{Acknowledgements}

This work was supported by the OSDIAC fund from ECCOREV research federation (ECCOREV-FR3098) and ODIAMAC project from ADEME French agency (Convention $\mathrm{n}^{\circ} 1506 \mathrm{C} 0034$ ) and from the Toulon University 2015-APRI-COMPOST. Part of the project was also supported by the Micro-Terra project. 


\section{References}

Amine-Khodja, A., Trubetskaya, O., Trubetskoj, O., Cavani, L., Ciavatta, C., Guyot, G., Richard, C., 2006. Humic-like substances extracted from composts can promote the photodegradation of Irgarol 1051 in solar light. Chemosphere 62: 1021-1027.

Baker, A., 2001. Fluorescence excitation-emission matrix characterization of some sewage-impacted rivers. Environmental Science and Technology 35: 948-953.

Baker, A., 2002. Fluorescence excitation-emission matrix characterization of river waters impacted by a tissue mill effluent. Environmental Science and Technology 36: 1377-1382.

Bernal, M.P., Paredes, C., Sánchez-Monedero, M.A., Cegarra, J., 1998. Maturity and stability parameters of composts prepared with a wide range of organic wastes. Bioresource Technology 63: 91-99.

Chen, Y., Senesi, N., Schnitzer, M., 1977. Information provided on humic substances by $\mathrm{E}_{4} / \mathrm{E}_{6}$ ratios. Soil Science Society of America Journal 41: 352-358.

Chen, W., Westerhoff, P.K., Leenheer, J.A., Booksh, K., 2003. Fluorescence excitationemission matrix regional integration to quantify spectra for dissolved organic matter. Environmental Science \& Technology 37: 5701-5710.

Coble, P.G., 1996. Characterization of marine and terrestrial DOM in seawater using excitation-emission matrix spectroscopy. Marine Chemistry 51: 325-346.

de Bertoldi, M., Vallini, G., Pera, A., 1983. The biology of composting: a review. Waste Management \& Research 1: 157-176.

De Haan, H., 1983. Use of ultraviolet spectroscopy, gel filtration, pyrolysis/mass spectrometry and numbers of benzoate-metabolizing bacteria in the study of humification and degradation of aquatic organic matter., in: R.F. Christman and E.T. Gjessing (Eds) (Ed.), Aquatic and Terrestrial Humic Materials. Ann Arbor Science Publishers, Ann Arbor, MI, pp. 165-182.

Domeizel, M., Khalil, A., Prudent, P., 2004. UV spectroscopy: a tool for monitoring humification and for proposing an index of the maturity of compost. Bioresource Technology 94: 177-184.

Duarte, R.M., Santos, E.B., Duarte, A.C., 2003. Spectroscopic characteristics of ultrafiltration fraction of fulvic and humic acids isolated from an eucalyptus bleached Kraft pulp mill effluent. Water Research 37: 4073-4080. 
Fuentes, M., González-Gaitano, G., José, M., García-Mina, J.M., 2006. The usefulness of UV-visible and fluorescence spectroscopies to study the chemical nature of humic substances from soils and composts. Organic Geochemistry 37: 19491959.

Gómez-Brandón, M., Lazcano, C., Domínguez, J., 2008. The evaluation of stability and maturity during the composting of cattle manure. Chemosphere 70: 436-444.

Guo, X., He, X., Zhang, H., Deng, Y., Chen, L., Jiang, J., 2012. Characterization of dissolved organic matter extracted from fermentation effluent of swine manure slurry using spectroscopic techniques and parallel factor analysis (PARAFAC). Microchemical Journal 102: 115-122.

He, X.S., Xi, B.D., Jiang, Y.H., He, L.S., Li, D., Pan, H.W., Bai, S.G., 2013. Structural transformation study of water-extractable organic matter during the industrial composting of cattle manure. Microchemical Journal 106: 160-166.

Jouraiphy, A., Amir, S., El Gharous, M., Revel, J.C., Hafidi, M., 2005. Chemical and spectroscopic analysis of organic matter transformation during composting of sewage sludge and green plant waste. International Biodeterioration \& Biodegradation 56: 101-108.

Kalbitz, K., Geyer, W., Geyer, S., 1999. Spectroscopic properties of dissolved humic substances - a reflection of land use history in a fen area. Biogeochemistry 47: 219-238.

Khalil, A., Domeizel, M., Prudent, P., 2008. Monitoring of green waste composting process based on redox potential. Bioresource Technology 99: 6037-6045.

Khalil, A.I., Hassouna, M.S., El-Ashqar, H.M.A., Fawzi, M., 2011. Changes in physical, chemical and microbial parameters during the composting of municipal sewage sludge. World Journal of Microbiology and Biotechnology 27: 2359-2369.

Larney, F.J., Blackshaw R.E., 2003. Weed seed viability in composted beef cattle feedlot manure. Journal of Environmental Quality 3: 1105-1113.

Li, A., Hu, J., Li, W., Zhang, W., Wang, X., 2009. Polarity based fractionation of fulvic acids. Chemosphere 77: 1419-1426.

Li, Y., Wang, S., Zhang, L., Zhao, H., Jiao, L., Zhao, Y., He, X., 2014. Composition and spectroscopic characteristics of dissolved organic matter extracted from the sediment of Erhai Lake in China. Journal of Soils and Sediments 14: 1599-1611. 
Luciani, X., Mounier, S., Redon, R., Bois, A., 2009. A simple correction method of inner filter effects affecting FEEM and its application to the PARAFAC decomposition. Chemometrics and Intelligent Laboratory Systems. 96: 227-238.

Marhuenda-Egea, F.C., Martínez-Sabater, E., Jordá, J., Moral, R., Bustamante, M. A., Paredes, C., Pérez-Murcia, M.D., 2007. Dissolved organic matter fractions formed during composting of winery and distillery residues: evaluation of the process by fluorescence excitation-emission matrix. Chemosphere 68: 301-309.

Milori, D.M.B.P., Martin-Neto, L., Bayer, C., Joao, M., Bagnato, V.S., Mielniczuk, J., 2002. Humification degree of soil humic acids determined by fluorescence spectroscopy. Soil Science 167: 739-749.

Mounier, S., Patel, N., Quilici, L., Benaïm, J.Y., Benamou, C., 1999. Fluorescence 3D de la matière dissoute du fleuve amazone (Three-dimensional fluorescence of the dissolved organic carbon in the amazon river). Water Research 33: 1523-1533.

Mustin, M., 1987. Le compostage, gestion de la matière organique. Edition Francois Dubus, Paris, PP. 954.

Nafez, A.H., Nikaeen, M., Kadkhodaie, S., 2015. Sewage sludge composting: quality assessment for agricultural application. Environmental Monitoring and Assessment 187: 1-9.

Parlanti, E., Wörz, K., Geoffroy, L., Lamotte, M., 2000. Dissolved organic matter fluorescence spectroscopy as a tool to estimate biological activity in a coastal zone submitted to anthropogenic inputs. Organic Geochemistry 31: 1765-1781.

Peuravuori, J., Pihlaja, K., 1997. Molecular size distribution and spectroscopic properties of aquatic humic substances. Analytica ChimicaActa 337: 133-149.

Pifer, A.D., Fairey, L., 2012. Improving on SUVA 254 using fluorescence-PARAFAC analysis and asymmetric flow-field flow fractionation for assessing disinfection byproduct formation and control. Water Research 46: 2927-2936.

Pype, M.L., Patureau, D., Wery, N., Poussade, Y., Gernjak, W., 2013. Monitoring reverse osmosis performance: conductivity versus fluorescence excitationemission matrix (EEM). Journal Membrane Science 428: 205-211.

Said-Pullicino, D., Erriquens F. G., Gigliotti, G., 2007a. Changes in the chemical characteristics of water-extractable organic matter during composting and their 
influence on compost stability and maturity. Bioresource Technology 98: 18221831.

Said-Pullicino, D., Kaiser, K., Guggenberger, G., Gigliotti, G., 2007b. Changes in the chemical composition of water-extractable organic matter during composting: distribution between stable and labile organic matter pools. Chemosphere 66: 2166-2176.

Sellami, F., Hachicha, S., Chtourou, M., Medhioub, K., Ammar, E., 2008. Maturity assessment of composted olive mill wastes using UV spectra and humification parameters. Bioresource Technology 99: 6900-6907.

Senesi, N., Miano, T.M., Provenzano, M.R., Gennaro, B., 1991. Characterization, differentation and classification of humic substances by fluorescencia spectroscopy. Soil Science 152: 259-271.

Shao, Z.H., He, P.J., Zang, D.Q., Shao, L.M., 2009. Characterization of water extractable organic matter during the biostabilization of municipal solid waste. Journal of Hazardous Materials 164: 1191-1197.

Stedmon, C.A., Markager, S., Bro, R., 2003. Tracing dissolved organic matter in aquatic environments using a new approach to fluorescence spectroscopy. Marine Chemistry 82: 239-254.

Stevenson, F.J., 1982. Extraction, fractionation, and general chemical composition of soil organic matter: In Humus chemistry, genesis, composition, reactions. John Wiley and Sons Eds, New York: 26-54.

Summers, R.S., Cornel, P.K., Roberts, P.V., 1987. Molecular size distribution and spectroscopic characterization of humic substances. Science of the Total Environment 62: 27-37.

Tang, Z., Yu, G.G.H., Liu, D.D.Y., Xu, D., Shen, Q., 2011. Different analysis techniques for fluorescence excitation-emission matrix spectroscopy to assess compost maturity. Chemosphere 82: 1202-1208.

Tian, W., Li, L., Liu, F., Zhang, Z., Yu, G., Shen, Q., Shen, B., 2012. Assessment of the maturity and biological parameters of compost produced from dairy manure and rice chaff by excitation-emission matrix fluorescence spectroscopy. Bioresource Technology 110: 330-337. 
Tomati, U., Galli, E., Pasetti, L., Volterra, E., 1995. Bioremediation of olive-mill wastewaters by composting. Waste Management \& Research, 13: 509-518.

Wang, Z., Wu, Z., Tang, S., 2009. Characterization of dissolved organic matter in a submerged membrane bioreactor by using three-dimensional excitation and emission matrix fluorescence spectroscopy. Water Research. 43: 1533-1540.

Wei, Z., Zhao, X., Zhu, C., Xi, B., Zhao, Y., Yu, X., 2014. Assessment of humification degree of dissolved organic matter from different composts using fluorescence spectroscopy technology. Chemosphere 95: 261-267.

Weishaar, J.L., Aiken, G.R., Bergamaschi, B.A., Fram, M.S., Fujii, R., Mopper, K., 2003. Evaluation of specific ultraviolet absorbance as an indicator of the chemical composition and reactivity of dissolved organic carbon. Environmental Science \& Technology 37: 4702-4708.

Yu, G.H., Luo, Y.H., Wu, M.J., Tang, Z., Liu, D.Y., Yang, X.M., Shen, Q.R., 2010. PARAFAC modelling of fluorescence excitation-emission spectra for rapid assessment of compost maturity. Bioresource Technology 101: 8244-8251.

Yu, G.H., Wu, M.J., Luo, Y.H., Yang, X.M., Ran, W., Shen, QR., 2011. Fluorecence excitation-emission spectroscopy with regional integration analysis for assessment of compost maturity. Waste Management 31: 1729-1736.

Zepp, R.G., Sheldon, W.M., Moran, M.A., 2004. Dissolved organic fluorophores in southeastern US coastal waters: correction method for eliminating Rayleigh and Raman scattering peaks in excitation-emission matrices. Marine Chemistry 89: $15-36$.

Zhang, J., Lv, B., Xing, M., Yang, J., 2015. Tracking the composition and transformation of humic and fulvic acids during vermicomposting of sewage sludge by elemental analysis and fluorescence excitation-emission matrix. Waste Management 39: 111-118.

Zhang, S., Chen, Z., Wen, Q., Zheng, J., 2016. Assessing the stability in composting of penicillin mycelial dreg via parallel factor (PARAFAC) analysis of fluorescence excitation-emission matrix (EEM). Chemical Engineering Journal 299: 167-176.

Zhao, H.Y., Li, J., Liu, J.J., Lü, Y.C., Wang, X.F., Cui, Z.J., 2013. Microbial community dynamics during biogas slurry and cow manure compost. Journal of Integrative Agriculture 12: 1087-1097. 
